\title{
Wight Loss And Type II Diabetes Mellitus Control After Laparoscopic Sleeve Gastrectomy In An Early Post-Operative Period- A Prospective Cohort Study
}

\author{
Shailesh $\operatorname{Kumar}^{1}$ (Corresponding Author), Md Abu Masud Ansari ${ }^{2}$, Umakant \\ Verma $^{3}$, Naveen Kumar ${ }^{4}$, Arun Kumar Gupta ${ }^{5}$, A.S.N Rao ${ }^{6}$ \\ ${ }^{1}$ (Professor Of Surgery, Pgimer, Dr. Rml Hospital New Delhi, India Mob. +919810477114, E-Mail ${ }^{2}$ (Assistant \\ Professor Of Surgery, Pgimer, Dr. Rml Hospital New Delhi, India. Mob. +919718490092, ${ }^{3}$ (Junior Surgical \\ Resident, Pgimer, Dr. Rml Hospital New Delhi, India.) \\ ${ }^{4}$ (Senior Surgical Resident, Pgimer, Dr. Rml Hospital New Delhi, India.) \\ ${ }_{5}^{5}$ (Professor Of Surgery, Pgimer, Dr. Rml Hospital New Delhi, India) \\ ${ }^{6}$ (Professor Of Surgery, Pgimer, Dr. Rml Hospital New Delhi, India)
}

\begin{abstract}
:
Introduction: Obesity has reached epidemic proportions worldwide India rank $3^{\text {rd }}$ after USA and China. The health consequences range from increased risk of premature death due to serious chronic illness like Hypertension and DM which reduces the overall quality of life. LSG produces long lasting control of Obesity as well as DM

Material and Methods: A prospective cohort study was conducted between the periods of January 2015 to March 2016. The criteria for selection were BMI $\geq 40 \mathrm{~kg} / \mathrm{m} 2$ or BMI $\geq 35 \mathrm{~kg} / \mathrm{m} 2$ with co-morbidities. All the patients were screened by a multidisciplinary team. All the patients were operated by the same surgeon to avoid any procedural biasness. At each follow-up visit, weight loss and glycemic control status were evaluated.

Results: Out of 60 patients operated for morbid obesity, Our focus were on those 18 patients who were morbidly obese having Diabetes as the only co morbidity .Rest were having either no co-morbidity or multiples comorbidity. Post operatively all patients were followed up and were given same diet plan for the first three months of the follow up. Post-operatively on follow up, there was significant change in all the parameters like the weight reduction, BMI, Fasting Blood sugar level, Post prandial Sugar level.

Conclusions: $L S G$ is simple, effective and reproducible surgical method to treat obesity as well as DM2.

Keywords: Diabetes Mellitus, Laparoscopic Sleeve Gastrectomy, Morbid obesity,

Abbreviations: LSG - Laparoscopic Sleeve Gastrectomy, BMI - Body Mass Index, FBS - Fasting Blood Sugar, PPBS - Post Prandial Blood Sugar, DM - Diabetes Mellitus, EWL-Excess Weight Loss.
\end{abstract}

\section{Introduction}

Obesity is defined by WHO as a chronic multisystem disease resulting from complex interaction between the human genotype and the environment. It has reached epidemic proportions worldwide. There are more than one billion overweight adults, of which at least 400 million are clinically obese [1]. More than 2.8 million adult die each year as a result of being overweight or obese. Overweight and obesity attributes $44 \%$ of diabetic, $23 \%$ of Ischemic heart disease and 7-41\% of cancer burden [2].

In Indian population, cross sectional study in Pune showed prevalence of obesity was $43 \%$ in adult population with statistically significant association between BMI $>25 \mathrm{~kg} / \mathrm{m}^{2}$ and diabetes and hypertension[3]. Several studies suggest that there is growing need to redefine morbid obesity in Asian population and also the Asians develop obesity related comorbid conditions at relatively younger age than their western counterparts [4]. Obesity has reached epidemic proportion in India [3].

The health consequences of obesity range from increased risk of premature death due to serious chronic illness like Hypertension and DM which reduces the overall quality of life [3] India a developing country is one of the capitals of diabetes and cardiovascular diseases. Development causes urbanization and reduction in physical activity leading to overweight and obesity.

Therapeutic interventions for the treatment of obesity range from lifestyle and diet modifications to pharmacologic and surgical therapy [5]. However, studies showed that the non-operative interventions for sustained weight loss usually fail to provide real benefits and are usually insufficient and not sustainable in comorbidly obese patients[6,7] Dietary, behavioral, and medication treatments for obesity are often unsuccessful for consistent weight loss[8].

Laparoscopic sleeve gastrectomy is an evidence based treatment of morbid obesity with proven, sustained weight loss and improvement in comorbidities $[9,10,11]$. The aim of this study was to evaluate the 
efficacy of Laparoscopic sleeve gastrectomy in morbidly obese patients in terms of weight loss and remission of DM.

Bariatric surgery is an effective and safe treatment for morbid obesity. The efficacy of bariatric procedures in the induction and maintenance of weight loss largely superior to that obtainable by current medical therapies and that has been confirmed by large meta-analyses [12-14]. This sustained weight loss has a profound impact on obesity-related comorbidities particularly type 2 diabetes.

There has been a substantial progress in the study of obesity and in the development of laparoscopic techniques of bariatric surgery Many types of operative procedures for morbid obesity have been popularized over the past three decades and are continuously evolving which range from restrictive to malabsorptive or combination of the two. It is difficult to identify the most effective option based on patient characteristics and comorbidities The LSG which removes $75-80 \%$ of the stomach is relatively easy, safer, less invasive and almost equally effective procedures for weight control and remission of DM2 as compared to Roux-en-Y gastric bypass.

\section{Materials and Method}

A prospective cohort study was conducted at PGIMER \& Dr R.M.L Hospital New Delhi between the periods of January 2015 to march 2016. Patients included were of either sex of age $18-60$ who had tried for weight loss for atleast 6 months by dietary restriction and life style modification but failed to maintain sustained weight loss. The criteria for selection were BMI $\geq 40 \mathrm{~kg} / \mathrm{m} 2$ or BMI $\geq 35 \mathrm{~kg} / \mathrm{m} 2$ with co-morbidity. All the patients were screened by a multidisciplinary team consisted of the surgeon, / nutritionist / cardiologist / endocrinologist / chest physician and a psychologist. All the patients were thoroughly evaluated and explained every concern including the risks and benefits of the procedures.

Diagnosis of T2DM was made according to the American Diabetes Association guidelines. T2DM remission was defined as a fasting plasma glucose level below $126 \mathrm{mg} / \mathrm{dl}$, PPBS < $200 \mathrm{mg} / \mathrm{dl}$, and Hb1Ac < $6.5 \%$ in the absence of hypoglycemic drugs $[10,15]$

The $\%$ of Excess weight loss was measured on each follow up visit. The BMI upto 25 were taken as the Normal weight and beyond that were taken as the Excess weight.

\subsection{Preoperative preparation:}

All routine investigations including Upper GI Endoscopy, echocardiography and psychological assessment for conducting LSG were done on every patient. $\square$ Patients were started on liver shrinkage diet one week prior to surgery. Deep venous thrombosis (DVT) prophylaxis with DVT Pump during surgery and subcutaneous LMWH was given to all patients $12 \mathrm{~h}$ before and continued for 7-10 days after the surgery.

\subsection{Surgical Method:}

A standardized procedure of LSG was performed using classical 5 ports under General Anaesethesia. All surgeries were done by the same surgeon to minimize the biasness. Omentolysis were started 3-5 cm from the pyloric junction up to the G-E Junction using ultracision. We cut sleeve over 36fr gastric calibration tube using Green cartridge for first two fires, rest all blue. Hemostasis was secured using metallic clips wherever required. Per-Operative leak test were performed using air inflation test in all patients. We routinely put 24Fr.drain along the sleeve. Specimen was removed and all ports $>10 \mathrm{~mm}$ were closed using transfascial suture.

\subsection{Postoperative period:}

Patients were observed in the high-dependency unit for the first night after the procedure. Patients were encouraged to sit out of bed and chest physiotherapy using Incentive spirometry on the evening after surgery in order to minimize postoperative atelectasis. Patients were allowed clear liquid on post op day 1 along with Maintenance intravenous fluid. Antibiotic and pro-kinetics were continued for a period of 5 days and 14 days respectively. Patients were discharged and followed up at 1 st week, $2^{\text {nd }}, 4^{\text {th }}$ week, and $12^{\text {th }}$ week. At each followup visit, weight loss and glycemic control status (FBS, PPBS, HbA1c and hypoglycemic treatment) were evaluated.

\subsection{Statistical Analysis:}

Categorical variables were presented in number and percentage $(\%)$ and continuous variables were presented as mean \pm SD and median. Statistical tests were applied as follows-

1Quantitative variables were compared using unpaired t-test/Mann-Whitney Test (when the data sets were not normally distributed) between the two groups.

2Qualitative variables were correlated using Chi-Square test /Fisher's exact test. The P value of $<0.05$ was considered statistically significant. 
The data was entered in MS EXCEL spreadsheet and analysis was done using Statistical Package for Social Sciences (SPSS) version 21.0. All of the results are presented as 2-tailed values with statistical significance defined as $P$ values $<0.05$.

\section{Results and Observations}

A total of 60 patients were operated for morbid obesity of the age ranging from 27 to 55 years with a mean of $41.53 \pm 8.89$ years and the male to female ratio is $3: 7$. The LSG were done on all patients by the same surgical team. The patients were selected randomly who came to our OPD. All patients were thoroughly investigated to rule out any reversible causes of obesity as well as any psychiatric, cardiac and respiratory problems including OSA Syndrome.

Our study focuses on those 18 patients who were morbidly obese having Diabetes as the only comorbidity, rest were having either no co-morbidity or multiples co-morbidity. Post operatively all patients were strictly followed up as per the research protocol and were given same diet plan for the first three months of the follow up.

The mean weight of the all morbidly obese patients pre-operatively was $111.03 \pm 8.78 \mathrm{Kg}$ (ranging from $100-130$ ) and the mean height was $1.6 \mathrm{~m}$ (ranging from 1.5-1.73) On follow up, the mean weight at $1^{\text {st }}$ week, $2^{\text {nd }}$ weeks, $4^{\text {th }}$ weeks and $12^{\text {th }}$ weeks reduced to $109 \pm 8.23 \mathrm{~kg}, 107.2 \pm 7.88 \mathrm{~kg}, 103.37 \pm 7.81 \mathrm{~kg}$ and $96.63 \pm$ $7.06 \mathrm{~kg}$ respectively. On statistical analysis it was found to be significant ( $\mathrm{P}$ value $<0.05$ ).

The Mean BMI of all the patients were $43.68 \pm 3.75 \mathrm{~kg} / \mathrm{m}^{2}$ Pre-operatively and on follow up the mean BMI reduced to $42.9 \pm 3.52 \mathrm{~kg} / \mathrm{m}^{2}, 42.09 \pm 3.26 \mathrm{~kg} / \mathrm{m}^{2}, 40.55 \pm 3.14 \mathrm{~kg} / \mathrm{m}^{2}$ and $38.01 \pm 2.31 \mathrm{~kg} / \mathrm{m}^{2}$ at $1^{\text {st }}$ week, $2^{\text {nd }}$ weeks, $4^{\text {th }}$ weeks and $12^{\text {th }}$ weeks respectively. All these observations were analyzed and found statistically significant $(\mathrm{P}$ value $<0.05)$

Table 1: correlation of Weight and BMI with post op period Fig.1: Weight and BMI trends following LSG

\section{Fasting blood sugar}

Out of 60 patients 18 patients had diabetes as the only co-morbidity. Their mean fasting blood sugar was $127.78 \pm 12.76 \mathrm{mg} / \mathrm{dl}$. At $1 \mathrm{st}$ week, $2^{\text {nd }}$ weeks, $4^{\text {th }}$ weeks and $12^{\text {th }}$ weeks, the mean value decreased to $118 \pm$ $6.24 \mathrm{mg} / \mathrm{dl}, 116.44 \pm 4.88 \mathrm{mg} / \mathrm{dl}, 109.89 \pm 5.62 \mathrm{mg} / \mathrm{dl}, 105.44 \pm 6.62 \mathrm{mg} / \mathrm{dl}$ respectively. All these observations were statistically significant $(\mathrm{P}$ value $<0.05)$

\section{Post prandial Blood Sugar}

The mean post prandial blood sugar of all 18 diabetic patients were recorded separately preoperatively and subsequent follow up and it was $208.11 \pm 19.37 \mathrm{mg} / \mathrm{dl}$ pre-operatively and $194.78 \pm 18.36 \mathrm{mg} / \mathrm{dl}$, $187.89 \pm 14.92 \mathrm{mg} / \mathrm{dl}, 177.78 \pm 13.28 \mathrm{mg} / \mathrm{dl}$ and $167.56 \pm 12.69 \mathrm{mg} / \mathrm{dl}$ after $1^{\text {st }}$ week, $2^{\text {nd }}$ week, $4^{\text {th }}$ week and $12^{\text {th }}$ week respectively. On statistical analysis theses were found significant (P value $<0.05$ ).

Table 2: Correlation of FBS \& PPBS with post op period

Fig. 2: FBS \& PPBS trends with post op period

\section{Serum HbA1C:}

The mean serum HbA1c of all 18 patients was $8.06 \pm 0.63 \%$. After 1 week the mean value decreased to $8.01 \pm 0.69 \%$ which was statistically not significant. Subsequently at $2^{\text {nd }}$ weeks, $4^{\text {th }}$ weeks and $12^{\text {th }}$ weeks, the mean value decreased to $7.72 \pm 0.8 \%, 7.34 \pm 0.58 \%$ and $6.88 \pm 0.44 \%$ respectively. All of these were statistically significant. ( $\mathrm{P}$ value $<0.05$ )

Table 3: Correlation of $\mathrm{HbA1c}$ level with post-op period

Fig. 3: HbA1c trends with post-op period

EWL: The \% of Excess weight loss were measured at each follow up visits and were recorded as $4.316 \%, 8.143 \%, 16.287 \%$ and $30.618 \%$ at $1^{\text {st }}$ week, $2^{\text {nd }}$ week $4^{\text {th }}$ week and $12^{\text {th }}$ week respectively.

Fig. 4: \% EWL trend with post-op period

\section{Discussion}

World Health Organization (WHO) Reveals in its report that obesity is one of the most common, yet among the most neglected, public health problems in both developed and developing countries [1]. According to Wild et al the prevalence of diabetes is expected to double globally from 171 million in 2000 to 366 million in 2030 with a maximum increase in India [3]. It is also predicted that by 2030 diabetes mellitus may afflict up to 79.4 million individuals in India only, while China (42.3 million) and the United States (30.3 million) would 
also see significant rise in those affected by the disease [3,4] Obesity is strongly associated with other comorbidity including diabetes, hypertension, dyslipidemia, cardiovascular disease and even some cancers [2].

There is a growing consensus that bariatric surgery is the predominant treatment option available for the management of morbid obesity and its associated co-morbid conditions. Diet therapy, medical treatment and different exercise \& yogas are relatively ineffective in treating morbid obesity in the long term [16]. Recently, the laparoscopic sleeve gastrectomy has emerged as a stand-alone procedure for the treatment of morbid obesity, and unlike the Roux-en-Y gastric bypass, the LSG does not bypass the foregut [17, 18].

The mechanisms of action of LSG are mechanical restriction and hormonal modulation. Ghrelin, a hunger-regulating peptide hormone, produced by P/D1 cells that are found mainly in the fundus of the stomach are removed, thus reducing plasma Ghrelin levels and subsequently, the feeling of hunger. Ghrelin regulation is also disturbed following the sleeve gastrectomy procedure. LSG was also reported to have a hindgut effect with increasing levels of glucagon-like peptide 1 and peptide YY due to the increased transit time after LSG [19].The $\%$ loss of excess weight at one year is $62 \%$ and $72 \%$ at two years [20-23]. In our study the $\%$ loss of excess weight was $4.316 \%, 8.143 \%, 16.287 \%$ and $30.618 \%$ at $1^{\text {st }}$ week, $2^{\text {nd }}$ week, $4^{\text {th }}$ week and $12^{\text {th }}$ week respectively which is significant and is consistent with the other studies. Similarly the mean BMI also reduced substantially in accordance with the earlier studies. It is expected that the loss of excess weight may be even more if patients follow the nutritional guidelines strictly, which is high protein low calorie diet and regular exercise.

A recent 3-year study of diabetic patients after LSG demonstrated an improvement in all comorbidities in 70\% of patients [24]. Significant improvement /remission of diabetic markers like Blood sugar level Fasting as well as PP), HbAlc is commonly observed after bariatric surgery [25-27]. Improvement of comorbid conditions was observed after LSG in more than half of the patients with type 2 diabetes [28, 29]. A remission of type 2 diabetes after LSG in $51 \%$ of patients after 4 months and $84 \%$ after 12 months as reported by Vidal et al $[30,31]$.

Similarly in our study, there are marked improvement in all the markers of the diabetes likes Blood sugar level (Fasting as well as PP), HbA1c and showed positive and significant change. Our results also observed that the improvement in diabetes occur early in the postoperative course. It was also observed that while these changes occur early, they are also durable [24]. The findings are also comparable with a recent review of 27 studies of sleeve gastrectomy; in that $66 \%$ resolution of diabetes with a mean follow up of 13 months [25]. In our study there was remarkable improvement of diabetes in all patients with reduction of diabetic medications after 2 wks of surgery.

The exact mechanism responsible for remission of diabetes after LSG has not yet been elucidated and necessarily excludes the bypass of the foregut theory, as has been suggested for the gastric bypass [31] As reported by others and supported by the results in this study, a significant reduction in diabetes markers and diabetic medications precedes maximal weight loss [32]. A systematic review of the existing literature showed that SG results in T2DM resolution ranging from $80 \%$ to $96 \%$ in morbidly obese subjects [33] a range similar to that in patients following RYGBP [34].

It is obvious from our study that positive change in all parameters of the DM started in the very first week and become statistically significant from the following week which continued till the last follow up visit in all Patients. The most probable cause of remission are removal of gastric hormones, including Ghrelin and peptide YY presents in the resected portion of the stomach has been found to be significantly reduced after LSG compared to gastric bypass [33]. There might be some changes in the milieu of other gut hormones which may play some role in remission. It is also not clear whether there is any change in the function of pancreatic endocrine and insulin resistance and further studies are needed in this direction.

\section{Conclusion}

LSG is simple and effective surgical procedure to achieve a significant weight loss and control of type 2 diabetes mellitus which starts in the early post-operative period. There is significant reduction in the diabetes medications hence the cost of diabetes treatment. A long term follow-up is needed to evaluate its effectiveness. 


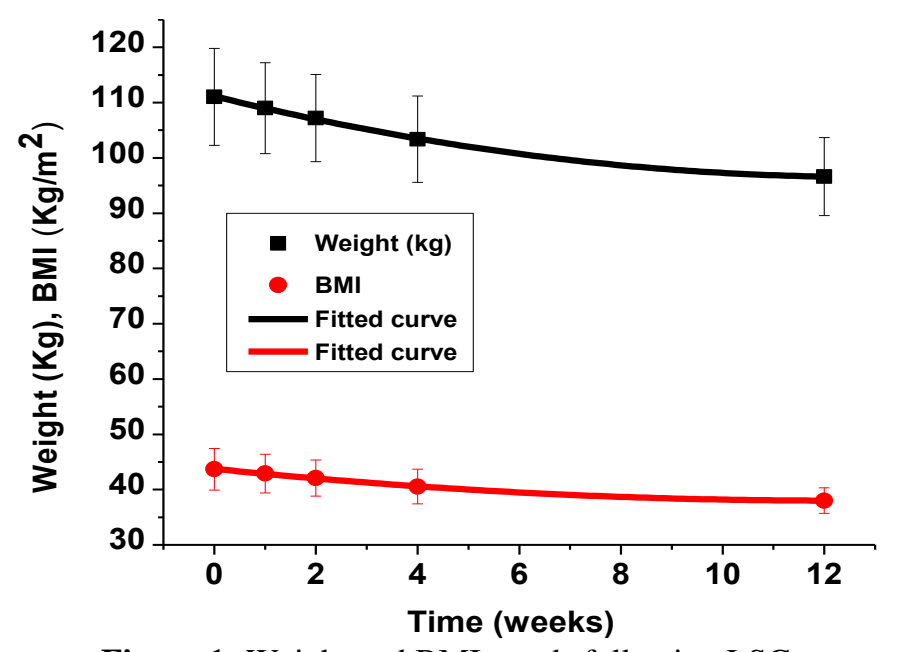

Figure 1: Weight and BMI trends following LSG

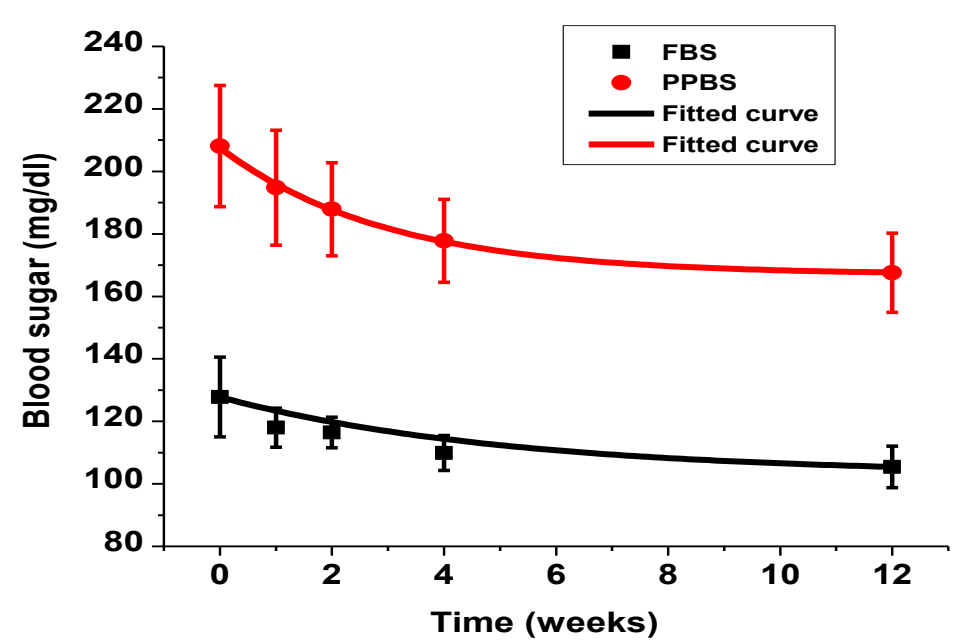

Figure 2: FBS \& PPBS trends with post op period



Figure 3: HbA1c trends with post-op period

Table 1: Correlation of Weight and BMI with post-op period 
Wight Loss And Type II Diabetes Mellitus Control After Laparoscopic Sleeve.....

\begin{tabular}{|c|c|c|c|c|c|c|c|}
\hline Duration & $\begin{array}{c}\text { Sample } \\
\text { size }\end{array}$ & Parameter & Mean $=S D$ & Median & Min-Max & $\begin{array}{c}\text { Inter quartile } \\
\text { Range }\end{array}$ & $P$ value \\
\hline \multirow[b]{2}{*}{0 Week } & \multirow[b]{2}{*}{60} & Weight (kgs) & $111.03=8.78$ & 110 & $100-130$ & $104-118$ & \\
\hline & & BMII & $43.68=3.75$ & 42.82 & $\begin{array}{l}37.63- \\
56.44\end{array}$ & $\begin{array}{l}41.400- \\
45.240\end{array}$ & \\
\hline \multirow[b]{2}{*}{1 Week } & \multirow[b]{2}{*}{60} & Weight (kgs) & $109=8.23$ & 108 & $98-126$ & $103-113$ & $<.00$ \\
\hline & & BMI & $42.9=3.52$ & 42.24 & $\begin{array}{c}37.63- \\
55.55\end{array}$ & $\begin{array}{c}40.620- \\
43.150\end{array}$ & $<.0005$ \\
\hline \multirow[b]{2}{*}{2 Week } & \multirow[b]{2}{*}{60} & Weight (kgs) & $107.2=7.88$ & 104.5 & $97-124$ & $101-112$ & $<.000$ \\
\hline & & BMII & $42.09=3.26$ & 41.43 & $\begin{array}{c}37.26- \\
53.33\end{array}$ & $\begin{array}{c}40.130- \\
42.570\end{array}$ & $<.0005$ \\
\hline \multirow[b]{2}{*}{4 Week } & \multirow[b]{2}{*}{60} & Weight (kgs) & $103.37=7.81$ & 100.5 & $94-120$ & $98-110$ & $<.0005$ \\
\hline & & BMII & $40.55=3.14$ & 39.6 & $\begin{array}{c}36.13- \\
51.11\end{array}$ & $\begin{array}{l}38.750- \\
41.870\end{array}$ & $<.0005$ \\
\hline \multirow[b]{2}{*}{12 Week } & \multirow[b]{2}{*}{60} & Weight (kgs) & $96.63=7.06$ & 95 & $84-112$ & $92-100$ & $<.0005$ \\
\hline & & BMI & $38.01=2.31$ & 37.48 & $\begin{array}{l}34.62- \\
44.44\end{array}$ & $\begin{array}{l}36.160- \\
38.620\end{array}$ & $<.0005$ \\
\hline
\end{tabular}

Table 2: Correlation of FBS \& PPBS with post-op period

\begin{tabular}{|c|c|c|c|c|c|c|c|}
\hline \begin{tabular}{|l|} 
Duration \\
Weeks
\end{tabular} & $\begin{array}{l}\text { Sample } \\
\text { size }\end{array}$ & Parameter & Mean $=$ St.dev & $\begin{array}{l}\text { Media } \\
\mathrm{n}\end{array}$ & Min-Max & Inter quartile Range & $\begin{array}{l}\mathrm{P} \\
\text { value }\end{array}$ \\
\hline \multirow[b]{2}{*}{0 Week } & \multirow[b]{2}{*}{18} & FBS & $127.78=12.76$ & 128 & $108-145$ & $117.250-137$ & \\
\hline & & PPBS & $208.11=19.37$ & 201 & $187-240$ & 194 & \\
\hline \multirow[b]{2}{*}{1 Week } & \multirow[b]{2}{*}{18} & FBS & $118=6.24$ & 118 & $106-130$ & $116-120$ & .020 \\
\hline & & PPBS & $194.78=18.36$ & 192 & $167-222$ & $180-206.500$ & .0002 \\
\hline \multirow[b]{2}{*}{$2 \mathrm{Week}$} & \multirow[b]{2}{*}{18} & FBS & $116.44=4.88$ & 116 & $110-126$ & $112-118.500$ & .022 \\
\hline & & PPBS & $187.89=14.92$ & 186 & $166-216$ & $176-197$ & .001 \\
\hline \multirow[b]{2}{*}{4 Week } & \multirow[b]{2}{*}{18} & FBS & $109.89=5.62$ & 110 & $98-120$ & $109.500-111.250$ & .001 \\
\hline & & PPBS & $177.78=13.28$ & 178 & $160-200$ & $167.500-187$ & .001 \\
\hline \multirow[b]{2}{*}{12 Week } & \multirow[b]{2}{*}{18} & FBS & $105.44=6.62$ & 106 & $90-112$ & $103.500-110$ & .0003 \\
\hline & & PPBS & $167.56=12.69$ & 170 & $150-189$ & $157.500-176$ & $\begin{array}{l}<.000 \\
5\end{array}$ \\
\hline
\end{tabular}

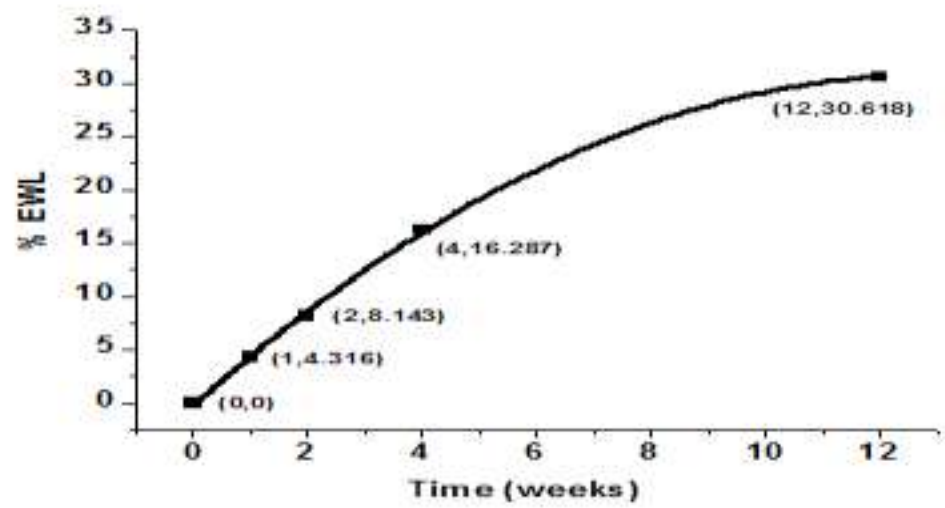

Figure 4: \% EWL trend with post-op period 
Table 3: Correlation of HbA1c level with post-op period

\begin{tabular}{|c|c|c|l|l|l|l|c|}
\hline & $\begin{array}{l}\text { Sampl } \\
\text { e size }\end{array}$ & \multicolumn{2}{|c|}{ Mean \pm Stdev } & Median & Min-Max & $\begin{array}{l}\text { Inter quartile } \\
\text { Range }\end{array}$ & P value \\
\hline & & & & & & & \\
\hline $0 \mathrm{~W}$ & 18 & $\begin{array}{l}8 . \\
6\end{array}$ & \pm 0.63 & 8 & $6.9-8.9$ & $7.725-8.575$ & \\
\hline & & & & & & & \\
\hline $1 \mathrm{~W}$ & 18 & $\begin{array}{l}8 . \\
1\end{array}$ & \pm 0.69 & 7.9 & $6.6-8.9$ & $7.775-8.575$ & .586 \\
\hline & & & & & & & \\
\hline $2 \mathrm{~W}$ & 18 & 7. & \pm 0.8 & 7.6 & $6.5-8.9$ & $7.325-8.200$ & .005 \\
\hline & & 2 & & & & & \\
\hline $1 \mathrm{M}$ & 18 & 7. & \pm 0.58 & 7.5 & $6.5-8.1$ & $6.900-7.775$ & .0002 \\
\hline & & 4 & & & & & \\
\hline $3 \mathrm{M}$ & 18 & 6. & \pm 0.44 & 7 & $5.9-7.5$ & $6.825-7.025$ & $<.0005$ \\
\hline & & & & & & & \\
\hline
\end{tabular}

\section{References}

[1]. World Health Organization. WHO fact sheets (Fact sheet No.311)[online]. Available at www.who.int/mediacentre/factsheets/fs311/en/. Accessed January 5, 2011

[2]. Lorein S D , George A K Dialysis: obesity and mortality on dialysis- does age matter? Nature Reviews Nephrol 2012;8: 258-60

[3]. Gothankar J S. Prevalence of obesity And Its Associated CoMorbidities Amongst Adults. Nat jour commun med 2011;2:221-4

[4]. Pan WH, Flegal KM, Chang HY, Yeh WT, Yeh CJ, Lee WC. Body mass index and obesity-related metabolic disorders in Taiwanese and US Whites and black: implications for definition of overweight and obesity for asians. Am J Clin Nutr 2004;79:31-9

[5]. Low A, Bouldin M, Sumrall C, Loustalot F, Land A: A clinician's approach to medical management of obesity. Am J Med Sci 2006, 33:175-182.

[6]. Weintraub M: Long-term weight control study: conclusions.Clin Pharmacol Ther 1992, 51:642-646.

[7]. Zhang F, Strain G, Lei W, Danger M, Pomp A: Changes in lipid profile in morbidly obese patient after laparoscopic sleeve gastrectomy (LSG).Obes Surg 2011, 21:305-309

[8]. Mason EE. Methods for voluntary weight loss and control. A National Institutes of Health Technology Assessment Conference, 30 March-1 April 1992, Bethesda, Maryland, USA. Obesity Surgery.1992;2(3):275-276. [PubMed]

[9]. Pories WJ, Swanson MS, MacDonald KG, Long SB, Morris PG, Brown BM,Barakat HA, de Ramon RA, Israel G, Dolezal JM, et al: Who would have thought it? An operation proves to be the most effective therapy foradult-onset diabetes mellitus. Ann Surg 1995, 222(3):339-350.discussion 350-332.

[10]. Sjostrom L, Narbro K, Sjostrom CD, Karason K, Larsson B, Wedel H, Lystig T,Sullivan M, Bouchard C, Carlsson B, et al: Effects of bariatric surgery on mortality in Swedish obese subjects. N Engl J Med 2007, 357(8):741-752.

[11]. World Health Organization. WHO fact sheets (Fact sheet N³11) September 2006

[12]. P. Gentileschi, I. Camperchioli, S. D’Ugo, D. Benavoli, and A. L. Gaspari, -Staple-line reinforcement during laparoscopic sleeve gastrectomyusing three different techniques: a randomized trial, Surgical Endoscopy. Surg Endosc. 2012 Sep;26(9):2623-9. doi: 10.1007/s00464-012-2243-2. Epub 2012 Mar 23.

[13]. Buchwald H, Estok R, Fahrbach K, et al. Weight and type 2 diabetes after bariatric surgery: systematic review and metaanalysis. Am J Med. 2009;122:248-56.

[14]. Buchwald H, Avidor Y, Braunwald E, et al. Bariatric surgery. A systematic review and meta-analysis. JAMA. 2004;292:1724-37.

[15]. Taylor RW, Kiel D, Gold EJ, Williams SM, Goulding A. Body mass index, waist girth and waist and hip ratioasindex of total and regional adopicity in women: Evaluation using receiver operating characteristic curves. Am J Clin Nutr. 1998; 67: 44-9.

[16]. Klein S, Sheard NF, Pi-Sunyer X, et al. Weight management through lifestyle modification for the prevention and management of type 2 diabetes: rationale and strategies. A statement of the American Diabetes Association, the North American Association for the Study of Obesity, and the American Society for Clinical Nutrition. Am J Clin Nutr 2004; 80:257-63

[17]. Gagner M, Deitel M, Kalberer TL, Erickson AL, Crosby RD. The second international consensus summit for sleeve gastrectomy, March 19-21, 2009. Surgery for Obesity and Related Diseases.2009;5(4):476-485. [PubMed]

[18]. Fuks D, Verhaeghe P, Brehant O, et al. Results of laparoscopic sleeve gastrectomy: a prospective study in 135 patients with morbid obesity. Surgery. 2009;145(1):106-113. [PubMed]

[19]. Ramachandran A, Ma RC, Snehalatha C. Diabetes in Asia. Lancet. 2010;375:408-418. [PubMed]

[20]. Boden G, Chen X, Ruiz J, White JV, Rossetti L. Mechanisms of fatty acid-induced inhibition of glucose uptake. J Clin Invest. 1994;93:2438-2446.

[21]. Unger RH. Lipotoxicity in the pathogenesis of obesity-dependent NIDDM: Genetic and clinical implications. Diabetes. 1995;44:863-870.

[22]. Niswender KD, Baskin DG, Schwartz MW. Insulin and its evolving part-nership with leptin in the hypothalamic control of energy homeostasis. Trends Endocrinol Metab. 2004;15:362-369.

[23]. Matsuzawa Y, Funahashi T, Kihara S, Shimomura I. Adiponectin and meta-bolic syndrome. Arterioscler Thromb Vasc Biol. 2004;24:29-33.

[24]. Todkar JS, Shah SS, Shah PS, Gangwani J. Long-term effects of laparoscopic sleeve gastrectomy in morbidly obese subjects with type 2 diabetes mellitus. Surgery for Obesity and Related Diseases.2010;6(2):142-145. [PubMed]

[25]. Gill RS, Birch DW, Shi X, Sharma AM, Karmali S. Sleeve gastrectomy and type 2 diabetes mellitus: a systematic review. Surgery for Obesity and Related Diseases. 2010;6(6):707-713. [PubMed]

[26]. Pories WJ, Swanson MS, MacDonald KG, et al. Who would have thought it? An operation proves to be the most effective therapy for adult-onset diabetes mellitus. Annals of Surgery. 1995;222(3):339-352.[PMC free article] [PubMed]

[27]. Abbatini F, Rizzello M, Casella G, et al. Long-term effects of laparoscopic sleeve gastrectomy, gastric bypass, and adjustable gastric banding on type 2 diabetes. Surgical Endoscopy and Other Interventional Techniques. 2010;24(5):1005-1010. [PubMed] 
[28]. Makary MA, Clarke JM, Shore AD, et al. Medication utilization and annual health care costs in patients with type 2 diabetes mellitus before and after bariatric surgery. Archives of Surgery. 2010;145(8):726-731.[PubMed]

[29]. Vidal J, Ibarzabal A, Romero F, et al. Type 2 diabetes mellitus and the metabolic syndrome following sleeve gastrectomy in severely obese subjects. Obesity Surgery. 2008;18(9):1077-1082. [PubMed]

[30]. Vidal J, Ibarzabal A, Nicolau J, et al. Short-term effects of sleeve gastrectomy on type 2 diabetes mellitus in severely obese subjects. Obesity Surgery. 2007;17(8):1069-1074. [PubMed]

[31]. Rubino F, Schauer PR, Kaplan LM, Cummings DE. Metabolic surgery to treat type 2 diabetes: clinical outcomes and mechanisms of action. Annual Review of Medicine. 2010;61:393-411. [PubMed]

[32]. Demaria EJ, Winegar DA, Pate VW, Hutcher NE, Ponce J, Pories WJ. Early postoperative outcomes of metabolic surgery to treat diabetes from sites participating in the ASMBS bariatric surgery center of excellence program as reported in the bariatric outcomes longitudinal database. Annals of Surgery.2010;252(3):559-566. [PubMed].

[33]. Gill RS, Karmali S, Sharma AM. Treating type 2 diabetes mellitus with sleeve gastrectomy in obese patients. Obesity (Silver Spring) 2011;19:701-702. [PubMed]

[34]. Buchwald H, Avidor Y, Braunwald E, Jensen MD, Pories W, Fahrbach K, Schoelles K. Bariatric surgery: a systematic review and meta-analysis. JAMA. 2004;292:1724-1737. [PubMed] 